\title{
HEALTHY SETTINGS IN HOSPITAL - HOW TO PREVENT BURNOUT SYNDROME IN NURSES: LITERATURE REVIEW
}

\author{
Adriano Friganović ${ }^{1,2}$, Irena Kovačević ${ }^{1}$, Boris $\operatorname{Ilić}^{1}$, Mirna $\check{Z} \mathrm{ulec}^{3}$, \\ Valentina Krikšić ${ }^{4}$ and Cecilija Grgas Bile ${ }^{5}$
}

${ }^{1}$ Department of Nursing, University of Applied Health Sciences;

${ }^{2}$ Clinical Department of Anesthesiology, Resuscitation and Intensive Care, Zagreb University Hospital Centre, Zagreb;

${ }^{3}$ Department of Nursing, Technical College, Bjelovar; ${ }^{4}$ Domnius Institution for Health Care at Home, Zagreb;

${ }^{5}$ Quality Control Department, Sestre milosrdnice University Hospital Centre, Zagreb, Croatia

SUMMARY - Healthy settings involve a holistic and multidisciplinary method that integrates actions towards risk factors. In hospital settings, a high level of stress can lead to depression, anxiety, decreased job satisfaction and lower loyalty to the organization. Burnout syndrome can be defined as physical, psychological and emotional exhaustion, depersonalization, and low sense of personal accomplishment. The aim of this literature review was to make systematic literature analysis to provide scientific evidence for the consequences of constant exposure to high levels of stress and for the methods to be used to prevent burnout syndrome among health care workers. The Medline database was searched to identify relevant studies and articles published during the last 15 years. The key words used in this survey were burnout syndrome, prevention, nurses, and healthy settings. The 6 eligible studies were included in literature review. Evidence showed nurses to be exposed to stress and to have symptoms of burnout syndrome. As a result of burnout syndrome, chronic fatigue and reduced working capacity occur, thus raising the risk of adverse events. In conclusion, the occurrence of burnout syndrome is a major problem for hospitals and healthcare system. Action plan for hospital burnout syndrome prevention would greatly reduce the incidence and improve the quality of health care.

Key words: Burnout, professional - prevention and control; Nurses; Risk factors; Stress, psychological; Fatigue syndrome, chronic

\section{Introduction}

A healthy setting represents an approach to health of workers and patients, which is holistic and multidisciplinary, and it integrates actions towards all the risk factors. An international network of hospitals promoting health has been established with the goal of orientating health institutions towards integration of health promotion and education, disease prevention, and rehabilitation services ${ }^{1}$.

Correspondence to: Adriano Friganović, Zagreb University Hospital Centre, Kišpatićeva 12, HR-10000 Zagreb, Croatia

E-mail: adriano@hdmsarist.hr

Received September 7, 2016, accepted April 21, 2017
The number of chronic patients is constantly increasing and demanding continuous support, along with hospital staff constant exposure to physical and emotional pressure, pointing to the need of activities directed to systemic approach. Hospitals can have heavy impact on the behavior of patients and their families, which should be more applicable to medical directions and advice, especially in the moment of facing sickness ${ }^{2}$. The prevalence of chronic diseases is becoming a big problem in Europe and the rest of the world with poor treatment response, and therapy education is becoming ever more significant ${ }^{3}$. Some of hospital treatments are directed towards the quality of life promotion and not exclusively to treatment. Burn- 
out syndrome in nurses represents a troublesome problem, affecting the patients, the staff and the health system in general in a very negative way. Healthcare represents a very challenging and high-risk work environment ${ }^{4}$. First burnout symptoms appears when a healthcare worker does not know how to or cannot deal with high stress levels ${ }^{5}$. As a consequence of burnout syndrome, nurses in some cases can develop addictions such as alcohol or drugs ${ }^{6}$. Nurse burnout syndrome often causes financial repercussions for the medical institution. The most common reasons of financial repercussions are absence from work, diminished work capability, higher risk of errors, or a combination of these factors. Emotional exhaustion and depletion of all emotional resources leads to depersonalization, creating a cynical and negative view of oneself and the work environment, and diminishes the sense of contentment ${ }^{7}$. The leading causes in the development of burnout syndrome are imbalance between work requirements and preparation and fitness for a work place, lack of control, insufficient performance recognition, and prolonged stress ${ }^{8,9}$.

The aim of this study was to summarize relevant literature and to describe evidence for the incidence of burnout syndrome in nursing population. Specific aims were to summarize the main sources for the incidence of burnout syndrome and effectiveness of prevention interventions.

\section{Materials and Methods}

The Medline database was searched to identify relevant studies and articles published during a 15-year period (2000-2015). The key words used were burnout syndrome, prevention, nurses, and healthy settings. The language restriction was that articles were published in English. Studies and review articles describing burnout syndrome in nursing population and prevention interventions were summarized. Literature selection was made as illustrated in Table 1.

\section{Results}

Search results are shown in Figure 1. Systematic review included 6 articles on cross-sectional studies.

This literature review was focused on cross-sectional study designs. An overview of the cross-sectional studies analyzed is shown in Table 2.
Table 1. Inclusion and exclusion criteria

\begin{tabular}{|c|c|c|}
\hline & Inclusion criteria & $\begin{array}{l}\text { Exclusion } \\
\text { criteria }\end{array}$ \\
\hline $\begin{array}{l}\text { Article } \\
\text { category }\end{array}$ & $\begin{array}{l}\text { - Systematic review } \\
\text { - Review article } \\
\text { - Original research }\end{array}$ & $\begin{array}{l}\text { - Letters } \\
\text { - Editorials }\end{array}$ \\
\hline Key words & $\begin{array}{l}\text { - Burnout syndrome } \\
\text { - Prevention } \\
\text { - Nurses } \\
\text { - Healthy settings }\end{array}$ & \\
\hline $\begin{array}{l}\text { Date of } \\
\text { publishing }\end{array}$ & - 2000-2015 & - Before 2000 \\
\hline Language & - English & - All other \\
\hline
\end{tabular}

\section{Discussion}

This review covered reasons for the incidence of burnout and based on these results we are able to offer possible solutions for health care institutions. Burnout syndrome is a significant problem in the healthcare system, especially in nurses because they represent the largest pool of healthcare workers. The impact of burnout symptoms on the work capacity and reduction of healthcare quality is important. Therefore, there is the need for designing action plans for burnout prevention and creating a healthy environment in hospitals. Nurses are frequently exposed to highly stressful and emotional situations at work, such as severe disease or death of patient.

Nursing educational programs do not provide enough knowledge about burnout, the factors known to be related to burnout, and the coping strategies. For this reason, it is very important for healthcare institutions to ensure appropriate programs for prevention and treatment of burnout. Literature review and analysis of 6 studies provided a large number of important and relevant scientific evidence. We identified 6 studies including 3248 nurses, conducted across the world and covering all continents. All the 6 studies included in literature review had a cross-sectional design. Review results pointed to the significance of the problem and the need for systematic measures for prevention. However, analysis of studies showed that the most common factors related to burnout were exclusion from decision-making process, need for greater autonomy, security risks, and staff issues. Our review findings suggest that, although the components of job 


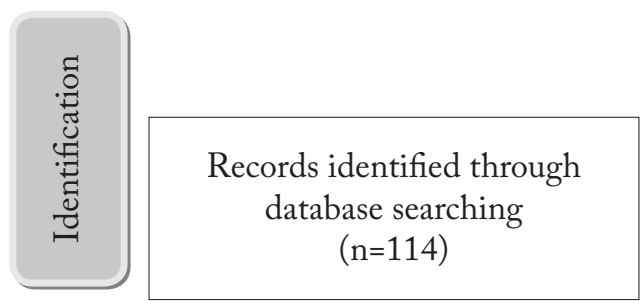

$$
\begin{aligned}
& \text { Additional records identified } \\
& \text { through other sources } \\
& (\mathrm{n}=0)
\end{aligned}
$$

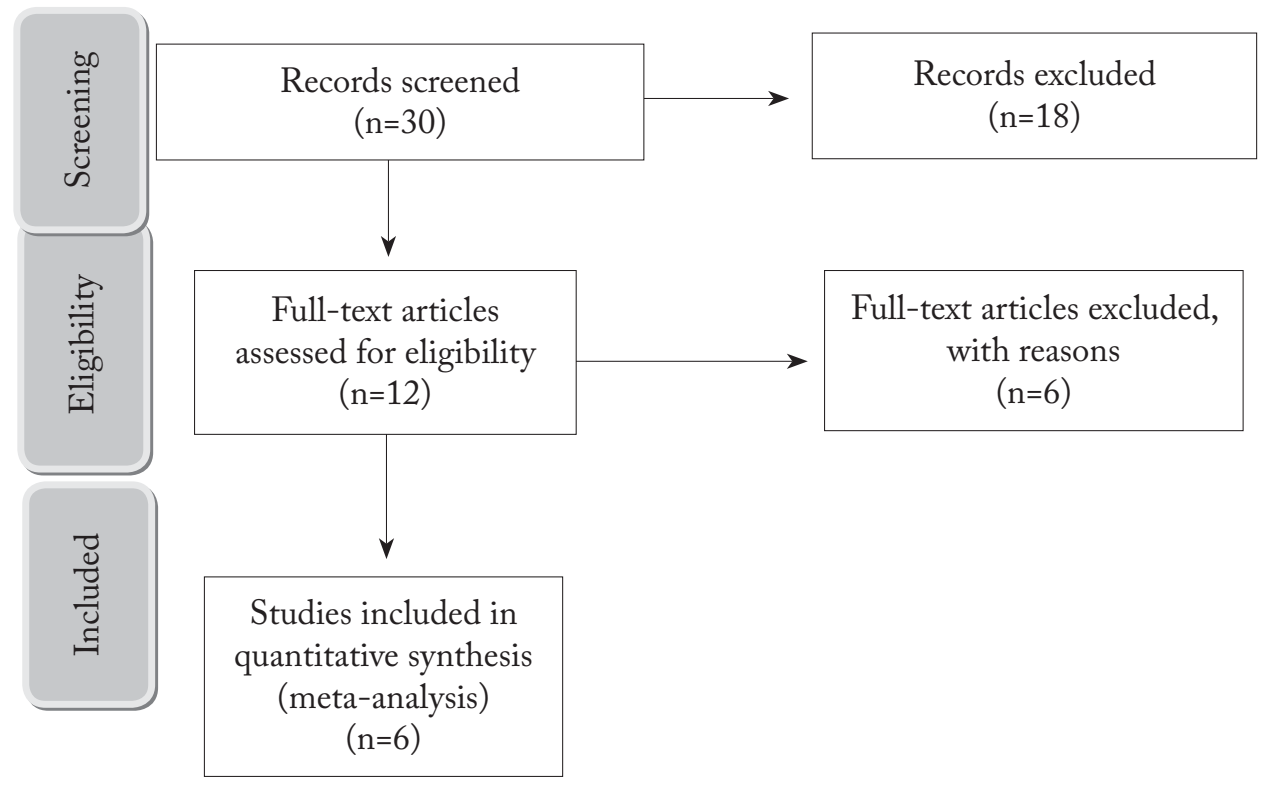

Fig. 1. Flow diagram.

satisfaction appear similar despite the use of different job satisfaction scales, a variety of measurements make direct comparison difficult, particularly in terms of their significance. The most common mistake is the belief that salary has the greatest impact on employee satisfaction. The findings reported by Van Boagaert et $a l .{ }^{10}$ showed the importance of nurses inclusion in decision-making processes. This study really highlights nursing management as an important aspect of increasing job satisfaction and prevention of burnout, and the authors demonstrated strong relationship between nursing management and quality of care and job outcome $^{10}$. On the other hand, Kamisha et al. ${ }^{11}$ revealed the staff issue to be important in determining burnout, as well as job satisfaction. This study findings also defined other stressors associated with burnout such as resource inadequacy and security risks, but did not find decision-making process to be crucial for decreased job satisfaction ${ }^{11}$. Ozden et al..$^{12}$ identified futility of care as a factor affecting job satisfaction and burnout experienced by nurses working in intensive care units. This paper gives a new perspective related to the futility dimension in nursing care and raising awareness among health professionals ${ }^{12}$. The study by Panunto et al. showed that nurses with greater autonomy experienced lower levels of emotional exhaustion, which was reflected in lower intention to leave their job, greater job satisfaction, and the perception of improved quality of care ${ }^{13}$. Results from this study correlate with the findings reported by Van Boagaert et $a l .{ }^{10}$ and identify nurses autonomy as a very important issue. The study by Light Irin and Bincy suggests that the stress management interventions are effective in reducing job stress among critical care nurses ${ }^{14}$. The study by Devinder et al. explored other perspectives of nursing care and the results showed that nurses with high emotional intelligence understood their own feelings and the feelings of the others, knew how to manage themselves and deal successfully with the others, and responded effectively to work demands ${ }^{15}$. As a 
Table 2. Studies surveyed in analysis

\begin{tabular}{|c|c|c|c|c|c|}
\hline Authors, year & Aim & $\begin{array}{l}\text { Type } \\
\text { of study }\end{array}$ & Population & Country & Results \\
\hline $\begin{array}{l}\text { Van Bogaert, } \\
\text { Kowalski, } \\
\text { Weeks, Van } \\
\text { heuseden, } \\
\text { Clarke }^{10} \\
(2013)\end{array}$ & $\begin{array}{l}\text { To explore the mechanisms } \\
\text { through which nurse practice } \\
\text { environment dimensions are } \\
\text { associated with job outcomes } \\
\text { and nurses-assessed quality } \\
\text { of care. }\end{array}$ & $\begin{array}{l}\text { Cross- } \\
\text { sectional } \\
\text { study }\end{array}$ & $\mathrm{N}=1201$ & Belgium & $\begin{array}{l}\text { The findings of this study } \\
\text { suggest that it is important } \\
\text { for clinicians and leaders to } \\
\text { consider how nurses are } \\
\text { involved in decision-making } \\
\text { about care process and } \\
\text { tracking outcomes of care } \\
\text { and whether nurses are able } \\
\text { to work with superiors, peers } \\
\text { and subordinates in a trusting } \\
\text { environment based on shared } \\
\text { values. }\end{array}$ \\
\hline $\begin{array}{l}\text { Kamisha, } \\
\text { Oldenburg, } \\
\text { Pletze, Ilic }{ }^{11} \\
\text { (2015) }\end{array}$ & $\begin{array}{l}\text { This study aimed at } \\
\text { identifying relationships } \\
\text { among work related stress, } \\
\text { burnout, job satisfaction and } \\
\text { general health among nurses. }\end{array}$ & $\begin{array}{l}\text { Cross- } \\
\text { sectional }\end{array}$ & $\mathrm{N}=1200$ & South Africa & $\begin{array}{l}\text { Researchers determined } \\
\text { stressors contributing to work } \\
\text { related stress. Staff issues } \\
\text { were found to be most } \\
\text { frequently associated with } \\
\text { burnout, as well as job } \\
\text { satisfaction. }\end{array}$ \\
\hline $\begin{array}{l}\text { Ozden, } \\
\text { Karagozoglu, } \\
\text { Yildirm }^{12} \\
(2013)\end{array}$ & $\begin{array}{l}\text { The study aimed to } \\
\text { investigate the levels of job } \\
\text { satisfaction and exhaustion } \\
\text { suffered by intensive care } \\
\text { nurses and the relationship } \\
\text { among them through the } \\
\text { futility dimension of the } \\
\text { issue. }\end{array}$ & $\begin{array}{l}\text { Cross- } \\
\text { sectional }\end{array}$ & $\mathrm{N}=138$ & Turkey & $\begin{array}{l}\text { This study revealed that } \\
\text { futility was one of the } \\
\text { factors affecting job } \\
\text { satisfaction and burnout } \\
\text { experienced by nurses } \\
\text { working in intensive care } \\
\text { units, and thus, it is expected } \\
\text { that it would contribute to } \\
\text { the literature since it could } \\
\text { raise awareness among health } \\
\text { professionals. }\end{array}$ \\
\hline $\begin{array}{l}\text { Panunto, } \\
\text { Guiradello }{ }^{13} \\
(2013)\end{array}$ & $\begin{array}{l}\text { The study aimed to evaluate } \\
\text { the characteristics of the } \\
\text { professional nursing practice } \\
\text { environment and its } \\
\text { relationship with burnout, } \\
\text { perception of quality of care, } \\
\text { job satisfaction and the } \\
\text { intention to leave the job in } \\
\text { the next } 12 \text { months. }\end{array}$ & $\begin{array}{l}\text { Cross- } \\
\text { sectional }\end{array}$ & $\mathrm{N}=129$ & Brazil & $\begin{array}{l}\text { Results have shown that } \\
\text { nurses with greater autonomy } \\
\text { experience lower levels of } \\
\text { emotional exhaustion, which } \\
\text { reflects lower intention to } \\
\text { leave their job, greater job } \\
\text { satisfaction, and the } \\
\text { perception of improved } \\
\text { quality of care. }\end{array}$ \\
\hline
\end{tabular}

secondary problem, burnout can lead to depression. Depression represents a global public health problem; it is an illness like all others, but is often unrecognized and untreated ${ }^{16}$. Moreover, as a consequence of burnout syndrome, some nurses may develop addictions to alcohol or drugs ${ }^{6}$.
Creating healthy settings can reduce the incidence of symptoms and improve the quality of the nursing care provided. Action plans for burnout syndrome prevention can be individualized, with two or more people involved, but plans should always aim to create a positive work environment where the possibility to develop 
Table 2. Continued

\begin{tabular}{|c|c|c|c|c|c|}
\hline $\begin{array}{l}\text { Light Irin, } \\
\text { Bincy }^{14} \\
(2012)\end{array}$ & $\begin{array}{l}\text { Identify the sources and } \\
\text { levels of stress for } \\
\text { nurses in the work } \\
\text { environment of critical care } \\
\text { units, to determine the effect } \\
\text { of stress management } \\
\text { interventions on the level of } \\
\text { stress of nurses working in } \\
\text { critical care units, and to find } \\
\text { out the association between } \\
\text { demographic variables and } \\
\text { the effect of stress } \\
\text { management interventions } \\
\text { on nurses working in critical } \\
\text { care units. }\end{array}$ & $\begin{array}{l}\text { Cross- } \\
\text { sectional }\end{array}$ & $\mathrm{N}=30$ & India & $\begin{array}{l}\text { Study findings suggest that } \\
\text { the stress management } \\
\text { interventions are effective in } \\
\text { reducing job stress among } \\
\text { critical care nurses. }\end{array}$ \\
\hline $\begin{array}{l}\text { Devinder, } \\
\text { Bambasivan, } \\
\text { Kumar }^{15} \\
(2013)\end{array}$ & $\begin{array}{l}\text { The study aimed to propose a } \\
\text { model of prediction of caring } \\
\text { behavior among nurses that } \\
\text { includes spiritual intelligence, } \\
\text { emotional intelligence, } \\
\text { psychological ownership and } \\
\text { burnout. }\end{array}$ & $\begin{array}{l}\text { Cross- } \\
\text { sectional }\end{array}$ & $\mathrm{N}=550$ & Malaysia & $\begin{array}{l}\text { The key findings are: } \\
\text { (1) spiritual intelligence } \\
\text { influences emotional } \\
\text { intelligence and psychological } \\
\text { ownership; } \\
\text { (2) emotional intelligence } \\
\text { influences psychological } \\
\text { ownership, burnout and } \\
\text { caring behavior of nurses; } \\
\text { (3) psychological ownership } \\
\text { influences burnout and } \\
\text { caring behavior of nurses; } \\
\text { (4) burnout influences caring } \\
\text { behavior of nurses; } \\
\text { (5) psychological ownership } \\
\text { mediates the relationship } \\
\text { between spiritual intelligence } \\
\text { and caring behavior and } \\
\text { between emotional } \\
\text { intelligence and caring } \\
\text { behavior of nurses; and } \\
\text { (6) burnout mediates the } \\
\text { relationship between spiritual } \\
\text { intelligence and caring } \\
\text { behavior and between } \\
\text { psychological ownership and } \\
\text { caring behavior of nurses. }\end{array}$ \\
\hline
\end{tabular}

the syndrome is reduced. Staffing levels also have great impact on job satisfaction in nursing profession ${ }^{17}$.

Nurses reported positive attitudes towards the expansion of nurses' authority and moderate attitudes to interpretation of diagnostic tests in selected situations ${ }^{18}$. Regardless of changes in the education of nurs- es, in most cases the autonomy of nursing and the physician-nurse relationship remain the biggest source of frustration and job dissatisfaction. Moral distress occurs when the nurse has trouble in acting according to his/her own morality due to an external barrier ${ }^{19}$. Unlike the types of conflict, in moral distress, the nurse 
is aware of the values and ethical principles involved in a situation, and is able to identify the action best suited to the care of the patient but cannot carry it out because someone or something prevents her/him doing so. The nurse, then, is unable to translate the moral decision or option into moral action ${ }^{20-22}$. Health promotion is increasingly cast as requiring the identification of best practices through careful and rigorous empirical evaluative research and applying these as faithfully as possible in practice, deviating as little as possible from what works according to the evidence ${ }^{21,23-26}$. The frequency of end of life decisions in nursing has increased in recent years as modern technology enables lives to be prolonged in the face of severe illness. This is not without effect on the staff involved in making and implementing such decisions and nurses have to continually adapt to the system changes and circumstances $^{22,27-30}$.

\section{Conclusion}

Considering that nurses play a key role in managing futile care, being aware of their experiences in this regard could be the initial operational step to compile useful caregiving and educational programs in intensive care units. Nursing managers should adopt supportive approaches and different strategies to reduce the incidence of burnout syndrome in nurses. Healthcare institutions should ensure preventive programs for nurses, as well as for other healthcare workers.

\section{References}

1. Groene O, Jorgensen SJ. Health promotion in hospitals - a strategy to improve quality in health care. Eur J Public Health. 2005;15(1):6-8. http://dx.doi.org/10.1093/eurpub/cki100

2. Florin D, Basham S. Evaluation of health promotion in clinical settings. In: Thorogood M, Coombes Y, editors. Evaluating Health Promotion. Practice and Methods. Oxford: Oxford University Press, 2000:140-50.

3. World Health Organization. Adherence to Long-Term Therapies. (http:// www.who.int/ncd/chronic_care/a_project) [accessed 10 October 2002].

4. Henderson J. The effect of hardiness eduaction on hardiness and burnout on registered nurses. Nurs Econ. 2015;33(4): 204-9.

5. Stordeur S, D’hoore W, Vanderberghe C. Leadership, organizational stress, and emotional exhaustion among hospital nursing. J Adv Nurs. 2001;35(4):533-42.
6. Miliken T, Clements P, Tillman H. The impact of stress management on nurse productivity and retention. Nurs Econ. 2007;25(4):203-10.

7. Awa LW, Plaumann M, Walter Ulla. Burnout prevention: a review of intervention programs. Patient Educ Couns. 2010; 78:184-90. DOI: 10.1016/j.pec.2009.04.008

8. Baker AB, Demerouti E, VerbekeW. Using the job demandsresources model to predict burnout and performance. Hum Resour Manage. 2004;43:83-104. DOI: 10.1002/hrm.

9. Schaufeli WB, Buunk BP. Burnout: an overview of 25 years of research and theorizing. In: Schabracq MJ, Winnubst JAM, Cooper CC, editors. The Handbook of Work and Health Psychology. $2^{\text {nd }}$ ed. West Sussex, England: Wiley, 2003:383-429.

10. Van Boagaert P, Kowalski C, Weeks SM, Van heusden D, Clarke $\mathrm{SP}$. The relationship between nurse practice environment, nurse work characteristics, burnout and job outcome and quality of nursing care: a cross-sectional survey. Int J Nurs Studies. 2013;50:1667-77. DOI: 10.1016/j.ijnurstu.2013.05.010

11. Kamisha N, Oldenburg B, Pletzer K, Ilic D. Work related stress, burnout, job satisfaction and general health of nurses. Int J Environ Res Public Health. 2015;12:652-66. DOI: 10.3390/ ijerph120100652

12. Ozden D, Karagozoglu S, Yildirm G. Intensive care nurses' perception of futility: job satisfaction and burnout dimensions. Nurs Ethics. 2013;20(4):436-47. DOI: 10.1177/0969733012 466002

13. Panunto MR, Guiradello EB. Professional nursing practice: environment and emotional exhaustion among intensive care nurses. Rev Latino-Am Enfermagem. 2013;21(3):765-72. DOI: $10.1590 /$ S0104-11692013000300016

14. Light Irin C, Bincy R. Effect of stress management interventions on job stress among nurses working in critical care units. Nurs J India. 2012;103(6):7-9.

15. Devinder K, Bambasivan M, Kumar N. Effect of spiritual intelligence, emotional intelligence, psychological ownership and burnout on caring behaviour of nurses: a cross-sectional study. J Clin Nurs. 2013;22:3192-202. DOI: 10.1111/jocn.12386

16. Kovačević I, Ozimec Vulinec Š, Krikšić V, Friganović A, Žulec M, Županić M. Čimbenici rizika u nastanku depresije. Hrvatski časopis za javno zdravstvo 2015;11(44):2-13. (in Croatian)

17. Kalisch B, Hee Lee K. Staffing and job satisfaction: nurses and nursing assistants. J Nurs Manag. 2014;22(4):465-71. DOI: 10.1111/jonm.12012

18. Kerzman H, Van Dijk D, Eizenberg L, Khaikin R, Phridman S, Siman-Tov M, Goldberg S. Attitudes toward expanding nurses' authority. Isr J Health Policy Res. 2015;1(4):19. DOI: $10.1186 / \mathrm{s} 13584-015-0005-\mathrm{z}$

19. Jameton A. Dilemmas of moral distress: moral responsibility and nursing practice. AWHONNS Clin Issues Perinat Womens Health Nurs. 1993;4:542-51.

20. Falco Pegueroles A, Lluch Canut T, Gua'rdia Olmos J. Development process and initial validation of the Ethical Conflict in 
Nursing Questionnaire-Critical Care Version. BMC Med Ethics. 2013;14(1):22. DOI: 10.1186/1472-6939-14-22

21. Poland B, Krupa G, McCall D. Settings for health promotion: an analytic framework to guide intervention design and implementation. Health Promot Pract. 2009;10(4):505-16. DOI: 10.1177/1524839909341025

22. Mc Millen RE. End of life decisions: nurses perceptions, feelings and experiences. Intensive Crit Care Nurs. 2008;24:251-9. DOI: $10.1016 /$ j.iccn.2007.11.002

23. Cazabat S, Barthe B, Cascino N. Work load and job stress: two facets of the same situation? Exploratory study in a gerontology department. Perspect Interdiscip Trav Santé. 2008;10:1-15.

24. Moustaka E, Constantinidis T. Sources and effects of workrelated stress in nursing. Health Sci J. 2010;4:210-6.

25. Aiken LH, Patrician PA. Measuring organizational traits of hospitals: the revised nursing work index. Nurs Res. 2000; 49(3):146-53.
26. Gasparino RC, Guirardello EB, Aiken LH. Validation of the Brazilian version of the Nursing Work Index-Revised (B-NWI-R). J Clin Nurs. 2011;20(23-24):3494-501. DOI: 10.1111/j.1365-2702.2011.03776.x

27. Landa JMA, Lopez-Zafra E. The impact of emotional intelligence on nursing: an overwiev. Psychology. 2010;1(1):50-8. DOI: $10.4236 /$ psych.2010.11008

28. Dulewicz V, Higgs M. Leadership at the top: the need for emotional intelligence in organizations. Int J Organizat Analysis. 2003;11:193. DOI: $10.1108 / \mathrm{eb028971}$

29. Benceković Ž, Benko I, Režek B, Grgas-Bile C. The role and promotion of nursing. Acta Clin Croat. 2016;55:271-8. DOI: 10.20471/acc.2016.55.02.14

30. Koić E, Mužinić-Masle L, Đorđević V, Vondraček S, CarMarković A. Primary prevention of burnout syndrome in nurses at General Hospital and Health Center from Virovitica, Croatia. Acta Clin Croat. 2001;40(4):259-71.

Sažetak

\section{ZDRAVA OKOLINA U BOLNICAMA: KAKO SPRIJEČITI SINDROM SAGORIJEVANJA KOD MEDICINSKIH SESTARA - PREGLED LITERATURE}

\section{A. Friganović, I. Kovačević, B. Iliç, M. Žulec, V. Krikšicí C. Rotim}

Zdrava okolina predstavlja pristup promicanja zdravlja koji uključuje holistički i multidisciplinarni pristup integrirajući akcije prema svim čimbenicima rizika. U bolničkoj okolini visoka razina stresa može dovesti do depresije, anksioznosti, smanjenog zadovoljstva poslom, ali i smanjene privrženosti radnoj organizaciji. Sindrom sagorijevanja može se definirati kao tjelesna i duševna iscrpljenost, osjećaj depersonalizacije i smanjeni osjećaj osobnog zadovoljstva. Ovaj pregledni članak daje sustavni pregled literature o posljedicama stalne izloženosti visokim razinama stresa kao i metodama kojima se može spriječiti sindrom sagorijevanja kod zdravstvenih radnika. Pretražena je baza podataka Medline kako bi se pronašle relevantne studije i članci objavljeni u posljednjih 15 godina. Ključne riječi u pretraživanju bile su sindrom sagorijevanja, prevencija, medicinske sestre i zdrava okolina. Pretragom je pronađeno 6 znanstvenih istraživanja koja su uključena u analizu. Dostupna literatura je pokazala kako medicinske sestre posljedično izloženosti stresu imaju simtpome sindroma sagorijevanja. Kao posljedica sindroma sagorijevanja javlja se kronični umor, smanjena radna sposobnost te visok rizik za neželjene događaje. Zaključuje se kako pojava simptoma sindroma sagorijevanja predstavlja velik problem za bolnice i zdravstveni sustav. Izrada akcijskog plana prevencije sindroma sagorijevanja u bolnicama uvelike bi smanjila pojavnost te unaprijedila kvalitetu pružene zdravstvene skrbi.

Ključne riječi: Sindrom sagorijevanja - prevencija i kontrola; Medicinske sestre; Čimbenici rizika; Stres, psibološki; Sindrom kroničnog umora 